\title{
Identifikasi Bakteri pada Komoditas Ikan Air Tawar di Balai Karantina Ikan, Pengendalian Mutu dan Keamanan Hasil Perikanan Surabaya I
}

\section{Bacterial Identification on Freshwater Fish Commodities at Fish Quarantine Center, Quality Control and Security of Fishery Products Surabaya I}

\author{
Nanik Ning Rahayu ${ }^{1 *}$, Prayogo ${ }^{2}$, Mohammad Faizal Ulkhaq ${ }^{2}$, Hapsari Kenconojati ${ }^{2}$, \\ Muhammad Hanif Azhar ${ }^{2}$ \\ ${ }^{1}$ Program studi Akuakultur, Fakultas Perikanan dan Kelautan, PSDKU Universitas Airlangga di \\ Banyuwangi \\ ${ }^{2}$ Dosen Program Studi Akuakultur, Fakultas Perikanan dan Kelautan, Universitas Airlangga \\ PSDKU Banyuwangi \\ J1. Wijaya Kusuma No. 133, Banyuwangi 68425, Indonesia \\ *Email: nanik.ning.rahayu-2016@fpk.unair.ac.id
}

\begin{abstract}
Abstrak
Distribusi pemasaran domestik dan ekpor membawa resiko masuk dan tersebarnya hama dan penyakit ikan, sehingga diperlukan adanya pengujian atau karantina untuk menghindari dampak negatif dari distribusi komoditas perikanan. Bakteri dapat menyebabkan kematian massal pada ikan dan kerugian bagi pembudidaya. Tujuan dari penelitian ini adalah untuk mengidentifikasi bakteri pada komoditas ikan air tawar. Penelitian dilaksanakan pada bulan Desember 2018 - Januari 2019 di Balai Karantina Ikan, Pengendalian Mutu, dan Keamanan Hasil Perikanan Surabaya I. Identifikasi bakteri dalam penelitian ini menggunakan metode konvensional. Parameter yang diamati yaitu gejala klinis eksternal yang nampak pada tubuh ikan dan patologi internal. Materi yang diperiksa dalam penelitian ini adalah ikan mas koki, benih ikan lele, benih ikan patin, benih ikan gurame dan ikan koi dengan jumlah total 64 sampel. Penelitian ini bersifat observatif, selanjutnya data yang diperoleh dianalisis secara deskriptif. Hasil penelitian menunjukkan bakteri yang teridentifikasi pada komoditas ikan air tawar dari 64 sampel di dominasi oleh bakteri Aeromonas hydrophila, Pseudomonas anguilliseptica, Streptococcus sp., Plesiomonas shigelloides, dan Micrococcus sp.
\end{abstract}

Keyword : Komoditas ikan air tawar, Bakteri, Metode konvensional

\begin{abstract}
The distribution of domestic and export marketing carries the risk of entering and spreading fish pests and diseases, so is it required identification or quarantine is needed to avoid negative impacts from the distribution of fishery commodities. Bacteria can cause high mortality in fish and loss for farmers. The purpose of this study is to identification bacteria in freshwater fish commodities. The study was conducted in December 2018 - January 2019 at the Fish Quarantine Center, Quality Control and Safety of Fisheries Products in Surabaya I. Identification of bacteria in this study using conventional methods. The parameters observed were external clinical symptoms that appeared on the body of the fish and internal pathology. The material examined in this study were The samples examined during Field Work Practices were Goldfish, Catfish fry, Common carp, and Koi fish with a total of 64 samples. This research was observative, then the data obtained were analyzed descriptively. The Result bacteria identified in freshwater fish commodities from 64 samples were dominated by Aeromonas hydrophila, Pseudomonas anguilliseptica, Streptococcus sp., Plesiomonas shigelloides, and Micrococcus sp
\end{abstract}

Keyword : : Freshwater fisheries commodities, Bacteria, The conventional method. 


\section{PENDAHULUAN}

Potensi budidaya ikan air tawar sangat besar untuk dikembangkan, komoditas ikan air tawar yang berpotensi antara lain ikan lele, ikan patin, ikan nila, ikan mas, ikan gurame, lobster air tawar dan spesies ikan tawar lainnya serta ikan hias air tawar. Menurut Badan Pusat Statistik Kementerian Perikanan dan Kelautan (2017) total produksi perikanan budidaya sebesar 17,22 juta ton, untuk produksi budidaya komoditas perikanan tawar sendiri sebesar 3.867.392 ton dan meningkat sebesar $3.26 \%$ dari tahun 2016. Terjadinya peningkatan jumlah produksi dan permintaan komoditas ikan air tawar baik konsumsi maupun hias di Indonesia akan membawa resiko masuk dan tersebarnya hama dan penyakit ikan yang berpotensi merusak kelestarian sumberdaya hayati perikanan.

Salah satu penyakit yang sangat berbahaya yaitu infeksi bakteri atau penyakit bakterial. Penyakit bakterial yang mungkin menyerang ikan air tawar antara lain Aeromonas hydrophila, A. salmonicida, Pseudomonas anguilliseptica, Streptococcus agalactiae, S. iniae, Vibrio sp., Edwardsiella tarda, E. ictaluri, Mycobacterium sp., Yersinia sp., dan Acinetobacter sp. (Murwantoko dkk., 2013). Kasus penyakit yang disebabkan oleh bakteri dapat menyebabkan kerugian yang besar bagi kegiatan budidaya, misalnya kematian massal. Salah satu kasus wabah penyakit Motile Aeromonas Septicemia (MAS) yang disebabkan oleh bakteri Aeromonas hydrophila pertama kali di Indonesia terjadi di Jawa Barat pada tahun 1980 yang menyebabkan kematian 82.2 ton dalam waktu 1 bulan (Angka, 2001).

Berdasarkan uraian di atas maka perlu dilakukan penelitian tentang identifikasi bakteri pada komoditas perikanan khususnya ikan air tawar. Hal tersebut bertujuan untuk mengetahui jenis bakteri yang dapat menyerang ikan air tawar dan upaya pencegahannya.

\section{METODE PENELITIAN}

\section{Waktu dan Tempat}

Penelitian ini dilaksanakan pada Desember 2018 - Januari 2019 di Balai Karantina Ikan, Pengendalian Mutu, dan Keamanan 
Hasil Perikanan Surabaya I, Sidoarjo, Jawa Timur.

\section{Persiapan Alat dan Bahan}

Semua peralatan yang digunakan seperti cawan petri, tabung reaksi, erlenmeyer, di bungkus dengan kertas dan dimasukkan ke dalam autoklaf dengan suhu $121^{\circ} \mathrm{C}$ dan tekanan 1 atm selama 15 menit. Sedangkan alat pembedahan cukup dengan menyemprotkan alkohol $70 \%$ dengan tujuan agar alat dalam kondisi steril (Champbell and Reece, 2005).

Pembuatan Media yaitu dengan cara menimbang media kemudian dimasukkan kedalam tabung erlenmeyer dan ditambahkan aquades. Media tersebut dipanaskan pada hot plate sambil diaduk hingga mendidih agar media tersebut homogen. Kemudian ditutup menggunakan aluminium foil dan dilakukan sterilisasi dengan autoclave. Proses sterilisasi dilakukan menggunakan autoclave dengan suhu $121{ }^{\circ} \mathrm{C}$ tekanan 1 atm selama 15 menit. Setelah dilakukan sterilisasi media di tunggu sampai suhunya menurun sekitar $50{ }^{\circ} \mathrm{C}$, kemudian dapat di tuang ke cawan petri atau tabung reaksi dan disimpan di lemari pendingin.

\section{Persiapan Sampel Uji}

Sampel ikan yang digunakan meliputi benih lele, benih ikan mas, benih ikan gurami, ikan mas koki, dan ikan koi. Selanjutnya dilakukan pemeriksaan gejala klinis. Parameter pemeriksaan gejala klinis pada bagian tubuh ikan, seperti mulut, sisik, perut dan insang ikan. Kemudian dilakukan uji laboratorium. Pengambilan organ target harus berdasarkan pada sifat HPIK dalam menginfeksi organ inang/carriernya. Organ yang diambil untuk pemeriksaan bakteri antara lain ginjal, hati, limpa, mata maupun otak ikan (ukuran ikan > 6 $\mathrm{cm})$ sedangkan ikan kecil (juvenile/sac fry) yang berukuran $<3$ $\mathrm{cm}$ adalah keseluruhan bagian tubuh dengan cara digerus. (Keputusan Kepala BKIPM Nomor 32/KEPBKIPM/2015).

\section{Isolasi Bakteri}

Isolasi bakteri dilakukan dengan mengambil isolat dari ginjal ikan karena ada bakteri tertentu yang terdapat didalam darah. Setelah mendapatkan organ target maka 
organ diambil menggunakan jarum ose steril lalu ditanam pada media TSA. Langkah selanjutnya diinkubasi selama 18-24 jam dengan suhu $37^{\circ} \mathrm{C}$. Kemudian setelah diinkubasi harus dilakukan pemurnian dengan cara mengambil koloni target dari bakteri dan ditanam pada media TSA baru kemudian $30^{\circ} \mathrm{C} \pm 2^{\circ} \mathrm{C}$ selama $18-24$ jam.

\section{Uji Presumtif dan Biokimia Bakteri}

Uji presumtif untuk menentukan sifat dasar dari mikroba yang diuji, dilakukan sebagai langkah karakterisasi umum dari bakteri yang terdiri dari uji gram, uji katalase, dan uji oksidase (Saputri dkk., 2016). Sedangkan uji biokimia dilakukan untuk mengetahui ciri fisiologis atau biokimia bakteri karena kemungkinan bakteri yang morfologinya sama memerlukan nutrisi dan persyaratan lingkungan yang mempunyai sifat biokimia yang berbeda. Hal ini sesuai dengan pernyataan Saputri dkk., (2016), bahwa uji biokimia ini dilakukan untuk menentukan genus dan jenis spesies. Uji biokimia terdiri dari uji TSIA, LIA, MIO, Urea, Gelatin,
Simmons Citrat, MR-VP, gula-gula dan $\mathrm{O} / \mathrm{F}$.

\section{Identifikasi Bakteri}

Identifikasi jenis bakteri dengan cara menyesuaikan hasil pengujian dan karakteristik bakteri yang sudah tersedia pada lembar identifikasi dengan menggunakan buku Biochemichal Tests for Identification of Medical Bacteria (Mac Faddin, 1980), buku Manual for the Identification of Medical Bacteria (Cowan and Steel's, 1993), Bergey's Manual of Determinative Bacteriology, dan Protokoler Instruksi Kerja Metode Balai KIPM Surabaya I.

\section{Parameter Pengamatan dan Analisa Data}

Parameter yang diamati yaitu gejala klinis eksternal dan internal pada ikan. Gejala klinis eksternal di lakukan dengan mengamati bagian tubuh luar ikan seperti sirip geripis, perut membengkak, sisik lepas, warna tubuh pucat, luka, mata menonjol (exphthalmia) dan lain sebagainya, sedangkan patologi internal yaitu dengan mengamati organ seperti hati pucat, kerusakan 
ginjal, pendarahan dan kerusakan organ dalam lainya.

Data yang diperoleh kemudian dianalisa secara deskriptif kualitatif dengan cara menguraikan hasil penelitian menggunakan rangkaian kata-kata.

\section{HASIL DAN PEMBAHASAN}

Gejala klinis yang muncul pada sampel ikan yang diperiksa tersaji pada Gambar 1.

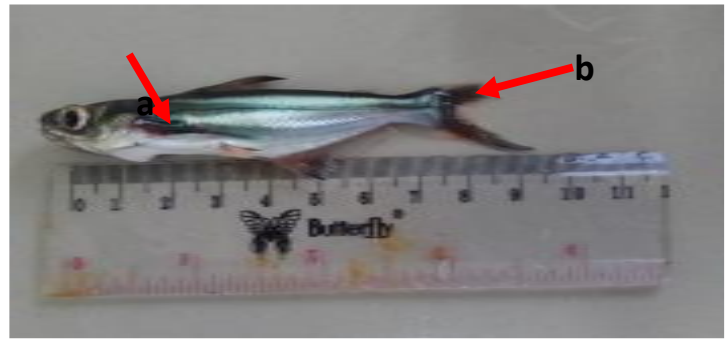

(A)

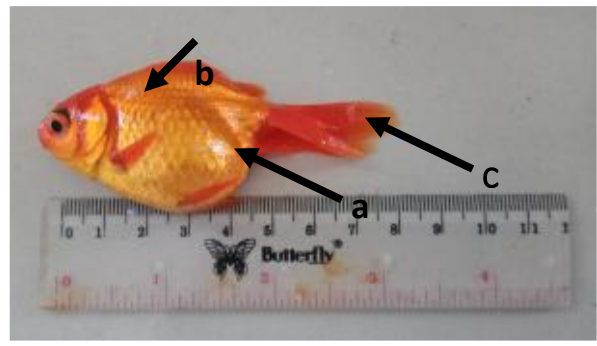

(B)

Gambar 1. A) Gejala klinis ikan patin sakit. (Keterangan a. luka dan pendarahan, b. sirip geripis), B) Gejala klinis ikan mas koki sakit. (Keterangan a. perut membengkak b. sisik lepas dan c. terdapat bintik putih pada sirip ekor.)

Tabel 1. Hasil Pengamatan Morfologi Koloni dan Uji Biokimia Isolat Bakteri

\begin{tabular}{|c|c|c|c|c|c|}
\hline \multirow{2}{*}{$\begin{array}{l}\text { Karakteristik } \\
\text { Uji }\end{array}$} & \multicolumn{5}{|c|}{ Hasil Identifikasi Bakteri pada Ikan Air Tawar } \\
\hline & 4673 & 4629 & 4637 & 0057 & 4618 \\
\hline Presumtif & & & & & \\
\hline Warna & Krem & Krem & Krem & Krem & Krem \\
\hline Bentuk & Bulat & Bulat & Bulat & Bulat & Bulat \\
\hline Tepi & Rata & Rata & Rata & Rata & Rata \\
\hline Elevasi & Cembung & Cembung & Cembung & Cembung & Cembung \\
\hline $\begin{array}{l}\text { Struktur } \\
\text { Dalam }\end{array}$ & Transparan & Transparan & Transparan & Transparan & Transparan \\
\hline Uji Gram & & & & & \\
\hline Bentuk & Batang & Batang & Bulat & Batang & Bulat \\
\hline Warna/Gram & Merah/Negatif & Merah/Negatif & Ungu/Positif & Merah/Negatif & Ungu/Positif \\
\hline Oksidase & + & + & + & + & - \\
\hline Katalase & + & + & - & + & + \\
\hline $\begin{array}{l}\text { Uji } \\
\text { Biokimia }\end{array}$ & & & & & \\
\hline $\mathrm{O} / \mathrm{F}$ & $\mathrm{F}$ & $\mathrm{O}$ & $\mathrm{F}$ & $\mathrm{F}$ & $\mathrm{O}$ \\
\hline $\begin{array}{l}\text { TSIA, Gas, } \\
\text { dan } \mathrm{H}_{2} \mathrm{~S}\end{array}$ & $\mathrm{Ak} / \mathrm{Ac}, \mathrm{G}, \mathrm{H}_{2} \mathrm{~S}$ & $\mathrm{Ak} / \mathrm{Ac}$ & Ac/Ac, $\mathrm{G}$ & $\mathrm{Ak} / \mathrm{Ac}$ & $\mathrm{Ak} / \mathrm{Ac}$ \\
\hline LIA (S/B) & + & + & + & - & + \\
\hline Motilitas & + & + & + & + & + \\
\hline Gelatin & + & - & - & + & - \\
\hline Indole & - & + & + & - & + \\
\hline Ornithine & + & + & + & + & + \\
\hline MR & + & + & + & + & + \\
\hline
\end{tabular}




\begin{tabular}{|c|c|c|c|c|c|}
\hline VP & + & - & - & - & - \\
\hline Simmons & + & - & + & - & + \\
\hline \multicolumn{6}{|l|}{ Citrate } \\
\hline Urease & + & + & + & - & + \\
\hline Glukosa & + & + & + & + & + \\
\hline Laktosa & + & - & - & + & - \\
\hline Sukrosa & + & + & + & + & + \\
\hline Arabinose & - & + & + & - & + \\
\hline Mannitol & - & + & + & - & + \\
\hline Maltose & + & + & + & + & - \\
\hline Trehalose & + & - & + & + & + \\
\hline Xylose & - & + & - & - & + \\
\hline Sorbitol & + & - & + & + & - \\
\hline Dulcitol & + & + & - & - & + \\
\hline Hasil & $\begin{array}{l}\text { Aeromonas } \\
\text { hydrophila }\end{array}$ & $\begin{array}{l}\text { Pseudomonas } \\
\text { anguilliseptica }\end{array}$ & $\begin{array}{l}\text { Streptococcus } \\
\text { sp. }\end{array}$ & $\begin{array}{c}\text { Plesiomonas } \\
\text { shigelloides }\end{array}$ & $\begin{array}{l}\text { Micrococcus } \\
\text { sp. }\end{array}$ \\
\hline
\end{tabular}

Hasil uji presumtif dan biokimia berdasarkan tabel di atas adalah bakteri Aeromonas hydrophila, Pseudomonas anguilliseptica, Streptococcus sp., Plesiomonas shigelloides, dan Micrococcus sp. Sedangkan berdasarkan gejala klinis eksternal beberapa bakteri menunjukkan gejala klinis yang sama seperti sirip geripis, perut membengkak, sisik lepas dan luka (Gambar 1 dan 2). Gejala patologi internal yang timbul antara lain ginjal pucat. Sehingga untuk mengetahui jenis bakteri yang menginfeksi di perlukan uji lanjutan.

\section{Aeromonas}

hydrophila merupakan bakteri gram negatif, berbentuk batang, ukuran $(0,8-1,0) \mathrm{x}$ $(1,0-3,5) \mu \mathrm{m}$, bergerak (motil) (Austin and Austin, 2007). Gejala klinis ikan yang terserang $A$. hydrophila yaitu bercak merah pada ikan, nafsu makan menurun, warna tubuh gelap, pergerakan lamban, sirip geripis, perut membengkak, luka/borok, mata menonjol (exopthalmia), kerusakan kulit, insang dan organ dalam (Haryani dkk., 2012). A. Hydrophila dapat menyerang hampir semua ikan air tawar golongan siluridae, cyprinidae, ictaluridae, dan clariidae seperti ikan lele, ikan mas, ikan mas koki, ikan gurami, dan ikan nila (Kismiyati dkk., 2009). Bakteri A. hydrophila adalah jenis bakteri yang bersifat pathogen oportunistik yang selalu ada di air dan siap menyerang apabila kondisi ikan kurang baik serta dapat menyebabkan penyakit 
sistemik serta mengakibatkan kematian (Haryani dkk., 2012).

\section{Pseudomonas anguilliseptica} dapat menyebabkan red spot disease (Hossain and Chowdhury, 2009). Gejala klinis ikan yang terserang bakteri $P$. anguilliseptica adalah terdapat luka/borok, perut kembung, exophtalmia, warna tubuh menjadi gelap, timbul pendarahan, gerakan lamban, sirip geripis, warna tubuh pucat, insang dan permukaan tubuh luka, hemoragik, lendir berlebih, dan sisik lepas serta diikuti hemoragik yang membentuk spot dikelilingi zona merah dan pendarahan pada organ dalam (Nurjanah dkk., 2014). $P$. anguilliseptica dapat menyerang ikan dari genus Anguilla, Carassius auratus, Oreochromis niloticus, Catfish sp., Pangasius spp. dan Common carp (Aekanurmaningdyah and Kurniasih, 2018).

Bakteri Streptococcus sp. adalah penyebab penyakit Streptococcosis atau yang disebut "syndrome Meningoencephalitis dan panophthalmitis" dengan gejala umum seperti: lemah, warna gelap, hilang nafsu makan, disorientasi atau hilang keseimbangan, uni/bilateral exophthalmia dengan kornea mata berwarna pucat, pendarahan dan luka pada bagian eksternal. Pada organ internal menunjukkan gejala adanya ascites, pembengkakan limpa, ginjal, hati, dan organ dalam lainnya. Spesies yang paling banyak ditemukan menyerang ikan adalah Streptococcus iniae dan Streptococcus agalactiae. Organ target dari serangan Streptococcosis adalah otak, mata dan ginjal (Taukhid dan Purwaningsih, 2011).

$$
\begin{aligned}
& \text { Plesiomonas shigelloides } \\
& \text { dapat menyebabkan penyakit }
\end{aligned}
$$
gastrointestinal. Gejala klinis ikan yang terinfeksi bakteri ini adalah nafsu makan menurun, kurus, dan pertumbuhan terhambat (Manurung, 2017).

Micrococcus sp. adalah bakteri berbentuk kokus, gram positif, fakultatif anaerob yang ditandai dengan reaksi oksidatif dan fermentative pada media $\mathrm{O} / \mathrm{F}$ (Holt $e t$ al., 2005). Bakteri ini dapat menyebabkan penyakit micrococcosis pada ikan. Gejala klinis ikan yang terinfeksi adalah timbulnya luka pada kulit dan organ internal seperti otot, liver, limpa dan penurunan nafsu makan (Aydin et al., 2005). 


\section{KESIMPULAN}

Hasil penelitian menunjukkan bakteri yang teridentifikasi pada sampel komoditas ikan air tawar di dominasi oleh bakteri Aeromonas hydrophila, Pseudomonas anguilliseptica, Streptococcus sp., Plesiomonas shigelloides, dan Micrococcus sp.

\section{DAFTAR PUSTAKA}

Aekanurmaningdyah, A and Kurniasih. 2018. Pathogenecity of Pseudomonas anguilliseptica Infection in Goldfish (Cyprinus carpio). International Journal of Cell Science and Molecular Biology, 4 (5): 001-006.

Anggraini, R., D. Aliza dan S. Mellisa. 2016. Identifikasi Bakteri Aeromonas hydrophila dengan Uji Mikrobiologi pada Ikan Lele Dumbo (Clarias gariepinus) yang dibudidayakan di Kecamatan Baitussalam Kabupaten Aceh Besar. Jurnal Ilmiah Mahasiswa Kelautan dan Perikanan Unsyiah, 1(2): 271286.

Angka, S. L. 2001. Studi Karakterisasi dan Patologi Aeromonas hydrophila pada Ikan Lele Dumbo (Clarias gariepinus). Makalah Falsafah Sains. Bogor: Progam Pasca Sarjana, Institut Pertanian Bogor.

Austin, B. and D. A. Austin. 2007. Bacterial Fish Pathogens Diseases of Farmed and Wild Fish. $4^{\text {th }}$ Edition. Praxis Publishing. Chichester. pp. 231238.
Aydin, S., A. Ciltas, H. Yetim, and I. Akyurt. 2005. Clinical, Pathological and Haematological Effects of Micrococcus luteus Infections in Rainbow Trout (Oncorhynchus mykiss Walbaum). Journal of Animal and Veterinary Advances. 4 (2): 167-174.

Badan Pusat Statistik Kementerian Perikanan dan Kelautan. 2017. Produktivitas Perikanan Indonesia Pada Forum Merdeka Barat 9 Kementerian Komunikasi Dan Informatika. Jakarta. Kementerian Kelautan dan Perikanan (KKP) RI.

Champbell, N. A. and J. B. Reece. 2005. Biology. $6^{\text {th }}$ Edition. Pearson Education, Inc. San Francisco. pp. 802-831.

Haryani, A., R. Grandiosa, I. D. Buwono dan A. Santika. 2012. Uji efektivitas daun pepaya (Carica papaya) untuk pengobatan infeksi bakteri Aeromonas hydrophila pada ikan Mas koki (Carassius auratus). Jurnal Perikanan dan Kelautan, 3 (3) : 213-220.

Holt, G. J., N. R, Krieg, P. H. A. Sneath, J. T. Stanley and S. T. Williams. 2005. Bergey's Manual Determinative Bacteriology. Lippincott Williams and Wilkins. Philadelphia. 787p.

Hossain, Md. Mer Mosharraf and Md. B. R. Chowdhury. 2009. Pseudomonas anguilliseptica As a Pathogen of Tilapia (Oreochromis niloticus) Culture in Bangladesh. Bangladesh Research Publications Journal, 2(4): 712-721.

Keputusan Kepala Badan Karantina Ikan Pengendalian Mutu dan Keamanan Hasil Perikanan Nomor 32/KEP-BKIPM/2015 Tentang Petunjuk Teknis 
Pemantauan Hama dan Penyakit Ikan Karantina.

Kismiyati, S. Subekti ., R. W. N. Yusuf dan R. Kusdarwati. 2009. Isolasi dan Identifikasi Bakteri Gram Negatif pada Luka Ikan Mas Koki (Carassius auratus) Akibat Infestasi Ektoparasit Argulus sp.. Jurnal Ilmiah Perikanan dan Kelautan, 1(2): 129-134.

Manurung, U. N. 2017. Identifikasi Bakteri Patogen Pada Ikan Nila (Oreochromis niloticus) Di Lokasi Budidaya Ikan Air Tawar Kabupaten Kepulauan Sangihe. Prosiding Seminar Nasional Kemaritiman dan Sumber Daya Pulau-Pulau Kecil II, 2(1) : 186-193.

Murwantoko., Rozi., I. Istiqomah., dan Kamiso H. Nitimulyo. 2013. Isolasi, Karakterisasi dan Patogenitas Bakteri Penyebab Penyakit pada Ikan Gurami (Osphronemus gouramy) di Kabupaten Bantul. Jurnal Perikanan (Journal Fish Science), 15 (2) : 83-90.

Nurjanah, S., S. B. Prayitno, dan Sarjito. Sensivitas Bakteri Aeromonas sp. dan Pseudomonas sp. yang Diisolasi pada Ikan Mas (Cyprinus carpio) Sakit Terhadap Berbagai Macam Obat Beredar. Journal of Aquaculture Management and Technology, 3 (4) : 308-316.

Saputri, R. A., N. Widyorini dan P. W. Purnomo. 2016. Identifikasi dan Kelimpahan Bakteri pada Jenis Karang Acropora sp. di Reef Flat Terumbu Karang Pulau Panjang Jepara. Jurnal Saintek Perikanan, 12 (1) : 35-39.

Taukhid dan U. Purwaningsih. 2011. Penapisan Isolat Bakteri Streptococcus spp. Sebagai Kandidat Antigen dalam
Pembuatan Vaksin, serta Efikasinya untuk Pencegahan Penyakit Streptococcosis pada Ikan Nila (Orechromis niloticus). Jurnal Riset Akuakultur, 6 (1) : 103-118. 